\title{
RETRENCHMENT AND LABOUR MARKET DISADVANTAGE: THE ROLE OF AGE, JOB TENURE AND CASUAL EMPLOYMENT
}

Industrial tribunals have been considering redundancy benefits for older workers, workers with long job tenure and casual workers (the latter group presently having no access to redundancy benefits regardless of tenure). This paper details labour market disadvantage faced by these categories of retrenched workers.

Misfortune in the labour market is unevenly distributed. Some groups are more likely than others to face labour market disadvantage, through such factors as a greater likelihood lose employment and to be: unable to find employment; without employment for longer periods of time once they are without employment; or forced into inferior jobs with lesser conditions or pay. This disadvantage may flow from 'personal' characteristics (such as gender, ethnicity, race), job characteristics (such as occupation, industry) or situational characteristics (such as region) (eg Pocock 1998; Alcorso \& Harrison 1993). Such characteristics may be used to segment labour markets, leading to people with similar capabilities receiving different pay and conditions (McNabb \& Ryan 1990). This article focuses on three particular characteristics (one 'personal', two related to the job) and their roles in one aspect of labour market misfortune - workers' experience after they have been retrenched. The characteristics are age, prior job tenure and casual/permanent employment status.

The focus is on these dimensions because they have particular policy salience. In 1984 the then Australian Conciliation and Arbitration Commission (ACAC) granted all award-covered employees severance benefits when made redundant. These were to range from four weeks pay for workers with one year of service to a maximum of eight weeks pay for workers with four or more years of service. No benefits were payable to casual employees or employees with less than one year service. At a time when many retrenched employees received no benefits, this was seen as a groundbreaking decision. Since then, the adequacy of these benefits has been challenged. 
Contention focuses on three areas. One is the adequacy of benefits for older workers, highlighted by the 1994 decision of the New South Wales Industrial Commission (NSWIC) to grant a 25 per cent loading in redundancy benefits to workers aged 45 and over. This is particularly salient in the light of evidence of discrimination against older (potential) workers. Discrimination against workers due to age or other grounds is well documented (eg Walley, Steinberg \& Waller 1999) and illegal under state and federal anti-discrimination laws. Yet these laws cannot prevent it, because they operate through complaints-based mechanisms and much discrimination is unobservable (Riach and Rich 1991). The level of severance benefits matters greatly as antidiscrimination laws are mostly of little use to aged retrenched workers.

A second contention is the adequacy of benefits for workers with longer prior tenure in their job. These benefits were in effect doubled by the NSWIC in 1994. Tenure, by implication, is closely related to age, but the advantage of tenure over age as a criterion for severance benefits is that it bears a direct relation to the 'service' provided by the employee to the employer.

The third focus is the exclusion of casuals from any redundancy benefits. At the time of the 1984 ACAC decision, casuals represented only a small proportion of workers and they tended to occupy predominantly short-term (and part-time) jobs. By 1998, 53 per cent of self-identified casuals had been in the same job for over a year; 24 per cent had been there for two years (ABS Cat No 6359.0). By November 200176 per cent of casuals still expected (some unrealistically) to be with the same employer in twelve months time (Australia 2003:172). This emergence of long-term casual employment is a 'recent phenomenon' (Australia 2003:152). Many casuals (perhaps over half) are not 'genuine' casuals in the sense of being people who are only engaged irregularly and for intermittent, short periods (Murtough \& Waite 2000). Rather, many are merely employees with regular work but insecurity of tenure, no redundancy pay and no rights to annual or sick leave. Controversy over the adequacy of 'casual' to describe the workers so hired has led to the ABS ceasing to use the term in its labour force statistics, instead identifying employees 'without leave entitlements'. This paper, however, uses the more common nomenclature, 'casuals'. 
The tribunal system has lightly regulated casual employees - they typically receive less training than permanent employees, have fewer career opportunities, lower employment entitlements such as superannuation and, as mentioned, no leave (by definition), little security of employment and no redundancy benefits (Campbell, 1996: 574). This has created an incentive for employers to concentrate growth in casual employment. Recent years have seen the start of a reconfiguration of the role of casual employment. The use of permanent part-time work is increasing, but fulltime work is becoming casualised. Thus, while the proportion of permanent employees who were part-time increased from 14 per cent to 16 per cent in the four years from 1999 to 2003, the proportion of casual employees who were full-time increased from 30 per cent to 35 per cent (ABS Cat No 6310.0). The exclusion of casuals from redundancy pay is increasingly affecting full-time workers, and the subject of industrial disputes, for example at the Sydney Hilton Hotel (Workers Online 2002).

These issues culminated in test cases sought by union peak councils to expand the scope and increase the generosity of severance payments in the Queensland and Australian Industrial Relations Commissions. Employers and the Commonwealth Government opposed any extension of these benefits, arguing, amongst other things, that the disadvantages claimed by unions did not exist or had been reduced in relative terms, that older workers were retiring earlier, that casuals received a loading which compensated for the risk of termination, and that the cost of any increase would hurt employers and cost jobs. It is not the purpose of this paper to address all these issues, but to focus on the question of the disadvantage faced by retrenched employees in relation to the three characteristics already mentioned.

This paper first considers the role of age in disadvantage regarding retrenchment, before turning to the related question of prior job tenure. Finally, it considers the situation for casual employees. It addresses the questions: are older retrenched workers and workers with longer prior job tenure disadvantaged compared to other retrenched workers; and are retrenched casuals at least as disadvantaged in the labour market as retrenched permanent employees?

\section{Data}


The main focus is on data from the Australian Bureau of Statistics (ABS). One source is the Labour Force survey (LFS). A number of supplementary surveys associated with the LFS are also used, primarily the Retrenchment and Redundancy (R\&R) survey, undertaken in July 1997 and July 2001, and from which unpublished data have been obtained. The LFS, being undertaken monthly, provides information from a potentially larger dataset than the episodic R\&R survey, which may only collect information from a defined sub-group in the population.

The two R\&R surveys were undertaken in different labour market contexts, with the national unemployment rate lower in July 2001 (6.9 per cent, seasonally adjusted) than in July 1997 (8.3 per cent). As a consequence of the better labour market situations, the estimated number of retrenched employees was lower over the three years to June $2001(596,400)$ compared to the three years to June 1997 (685,400). In a labour market characterised by lower unemployment, the labour market outcomes for retrenched employees were also more favourable over the later period, with 16.6 per cent of employees who had been retrenched in the three years to June 2001 still unemployed in July 2001, whereas the comparable figure for July 1997 was 29.3 per cent. As a consequence, unemployment duration amongst retrenched employees also declined. However, in July 2001, 16.2 per cent of employees who had been retrenched in the preceding three years were now 'not in the labour force', compared to 16.0 per cent in July 1997.

In interpreting changes between the 1997 and 2001 data, it is important to recognise that both sets of data are subject to sampling error. Because of the lower rates of redundancy and unemployment in the later period, most estimates in tables for 2001 tend to have higher standard errors and lower reliability than comparable estimates for 1997.

\section{Age}

Before turning to the specifics of the R\&R surveys, we first consider general data on age from the LFS. There is considerable evidence of a higher level of disadvantage faced by older people (Walley, Steinberg \& Waller 1999:10), whom employers are reluctant to take on (VandenHeuvel, 1999). 
We focus initially on unemployment duration as a key indicator of labour market disadvantage. This is because people with longer periods of unemployment duration are more likely to experience hardship, for example through exhausting financial resources, and becoming disillusioned and depressed. Table 1 considers LFS data on unemployment duration by age. 'High duration' unemployment refers to unemployment with observed duration of 26 or more weeks. (Note that the LFS does not measure completed unemployment spells, rather it observes duration of the unemployment spell to date which will be, on average, half way through their period of unemployment. Hence the average person unemployed for 26 weeks at the time of the survey will end up unemployed for about a year before obtaining a job.)

In the June quarter 1997 around two thirds of over 55 year old unemployed persons experienced high duration unemployment, compared to no more than half of those under 55 years. In 2001 the proportion of high duration unemployed in both groups fell, but the fall was proportionately smaller for the over 55 age group (the fall of 9 percentage points represented a drop of 14 per cent for the over 55 age group, compared to 24 per cent for the under 55 year olds). As a consequence, whereas in June quarter 1997 an unemployed person over 55 years was 1.5 times as likely to be experiencing high duration unemployment as an under 55 year old, by June quarter 2001 they were 1.7 times as likely. 
Table 1 Proportion of unemployed persons with high duration unemployment and incidence of high duration unemployment, by age, June quarters, 1997, 2001

\begin{tabular}{|l|c|c|}
\hline \multicolumn{1}{|l|}{$\begin{array}{l}\text { Proportion of unemployed persons with high } \\
\text { duration unemployment }\end{array}$} & 1997 & 2001 \\
\hline aged 55 and over & $67 \%$ & $57 \%$ \\
\hline aged 54 and under & $44 \%$ & $34 \%$ \\
\hline $\begin{array}{l}\text { Incidence of high duration unemployment - ratio of } \\
\text { aged 55+ to 54 and under }\end{array}$ & 1.5 & 1.7 \\
\hline
\end{tabular}

Source: ABS, Labour Force, Australia, Cat No 6203.0, various months.

Population: Unemployed persons

High duration unemployment refers to unemployment with an observed (not completed) duration of at least 26 weeks.

\section{Retrenchment and redundancy}

Just as older employees are disadvantaged in the labour market, so too they are disadvantaged when retrenched. There is near 'unanimous' agreement in the literature that 'age is negatively related to the likelihood and speed of re-employment' of retrenched workers (Wooden, 1988:6). Once unemployed, 'mature workers often find it extremely difficult to regain work, for a range of reasons; from employers attitudes of who and what is an older worker, to a lack of qualifications or skills' (Walley, Steinberg \& Waller 1999:8,9). The R\&R survey shows that, in 1997, 65 per cent of unemployed persons aged 55 and over had been unemployed for 26 weeks or more, compared to 37 per cent of unemployed 24 to 34 year olds.

Of course, unemployment duration does not indicate the full extent of labour market disadvantage faced by various groups in the labour market. Some people may leave the labour force altogether - for example, they may eventually give up looking for work if, after a period of job search, they are unable to find suitable employment (VandenHeuvel, 1999:16). The ABS supplementary survey on successful and unsuccessful job search experience reveals that jobseekers in older age groups were least likely to be successful in finding a job (ABS Cat No 6245.0, July 2000, p5). Data on labour force exit incorporate the effect of discouraged job 
seekers - people who would like a job but who no longer satisfy the ABS definition of unemployment - and people who have given up hopes of employment altogether. Discouraged job seeking is a particular problem amongst mature age people. For example, 'discouraged job seekers make up a considerably larger percentage of the population of older male workers (over 55 years) than of younger makes. For women, the differences by age are even larger' (VandenHeuvel 1999:16-17; see also Walley, Steinberg \& Waller 1999: 9).

The data from the redundancy and retrenchment survey did not include specific counts of discouraged job seekers. However, a related, useful indicator of need amongst retrenched employees from this survey is the proportion not in work - they are either unemployed or not in the labour force. Table 2, from the R\&R survey, shows that older retrenched persons, particularly those aged 55 and over, had a higher probability of being either unemployed or not in the labour force than their younger counterparts. 
Table 2. Percentage unemployed or not in the labour force, by age group and employment status of previous job.

\begin{tabular}{|l|l|l|l|l|l|l|l|}
\hline \multicolumn{2}{|l|}{$\begin{array}{l}\text { Proportion unemployed or not in the labour force, } \\
\text { July 1997, by Age group }\end{array}$} \\
\hline & $\begin{array}{l}18-24 \\
(\%)\end{array}$ & $\begin{array}{l}25-34 \\
(\%)\end{array}$ & $\begin{array}{l}35-44 \\
(\%)\end{array}$ & $\begin{array}{l}45-54 \\
(\%)\end{array}$ & $\begin{array}{l}55-64 \\
(\%)\end{array}$ & $\begin{array}{l}\text { All } \\
(\%)\end{array}$ \\
\hline $\mathbf{1 9 9 7}$ & 40.9 & 34.8 & 33.4 & 39.3 & 67.7 & 40.4 \\
\hline permanent & 62.3 & 53.2 & 53.9 & 55.6 & 66.1 & 57.3 \\
\hline casual & 51.4 & 40.7 & 38.1 & 42.4 & 67.4 & 45.3 \\
\hline all employees & 30.8 & 26.9 & 25.4 & 28.5 & 51.1 & 30.2 \\
\hline 2001 & 49.6 & 34.6 & 30.8 & 43.6 & $47.3^{*}$ & 40.8 \\
\hline permanent & 39.7 & 28.9 & 26.5 & 31.7 & 50.8 & 32.8 \\
\hline casual & & & & & \\
\hline all employees & &
\end{tabular}

Source: ABS Cat No 6266.0, unpublished data.

Population: Persons aged 18 to 64 years who had been retrenched or made redundant in the three years to 30 June 1997/2001.

\section{Early retirement?}

Do these patterns regarding older workers simply reflect a trend towards early retirement? After all, in its submissions to the 2003 AIRC test case, the Commonwealth relied in part on arguments that many older and longer-tenure retrenched workers were simply choosing to retire early, and so their status as being 'not in the labour force' indicated nothing about their level of disadvantage. (Australia 2003:181).

This argument is difficult to sustain. Data presented earlier show the growing problem of high duration unemployment amongst older workers. Just as significantly, the idea that early retirement was increasingly common is simply a myth. Labour force participation rates increased in all three older age groups (45-54, 55-59 and 60-64 year olds) between 1997 and 2001. For example, between June quarter 1997 and June quarter 2001, the participation rate amongst 55-59 
year olds increased from 57.7 per cent to 61.4 per cent, and amongst 60-64 year olds it increased from 32.2 to 34 per cent. ${ }^{1}$ If these data are indicating anything about retirement patterns, it is that people were retiring later, not earlier, in the later year.

Moreover, if retrenched employees were 'retiring' at the times they do through genuine choice, we would expect the distribution of retirement ages amongst retrenchees to be similar to the distribution amongst people who choose their retirement date. Yet the ABS Retirement and Retirement Intentions Survey indicates that, amongst persons who retired after reaching the age of 45 years, 68 per cent of those who lost their last job due to retrenchment 'retired' before reaching age 60 years, compared to only 45 per cent amongst all 'job leavers' and 56 per cent amongst those who left their last job for reasons associated with early retirement ('early retirement package', 'eligible for superannuation or service pension').

The rate at which retrenched employees leave the labour force is also considerably higher than in the labour force as a whole. In 2000 an estimated 208,000 employees were retrenched. These employees were retrenched between $61 / 2$ and $181 \frac{1}{2}$ months before the July 2001 survey, that is, an average of slightly over 12 months before the survey. Amongst those retrenched workers, some 32,800 or 15.8 per cent had left the labour force by the time of the survey. By comparison, the Labour Mobility survey shows that only 3.8 per cent of all people employed in February 2001 had left the workforce 12 months later, by February 2002 (ABS Cat No 6209.0). This discrepancy is not because retrenchments are concentrated amongst older workers since this group appeared no more likely than any other cohort to become retrenched. The principal problem for older workers is not that they are more likely to be retrenched, it is that their subsequent employment prospects are bleaker than those of other workers. Hence, once retrenched, many older workers leave the labour market (or at least cease looking for work actively enough to satisfy the ABS definition of unemployed).

1 For 45-54 year olds the increase was from 78.3 per cent in June quarter 1997 to 79.0 per cent in June quarter 2001 and 80.1 per cent in June quarter 2002. 
Some employees facing redundancy situations may voluntarily choose redundancy because they are close to retirement and might prefer to retire early anyway. This mainly occurs amongst employees with unions able to negotiate voluntary redundancy frameworks in the context of enterprise bargaining arrangements. For those employees reliant on awards, voluntary redundancy is less common, and those with long tenure who face retrenchment normally do not have a say in whether or not they are made redundant. In unionised workplaces, unions are often able to demand voluntary redundancy programs of management, whereas in non-union workplaces this form of downsizing is relatively rare and compulsory retrenchments are more common. The 1995 Australian Workplace Industrial Relations Survey (AWIRS - see Morehead, Steele, Alexander, et al 1997) revealed that compulsory retrenchments were more common in non-union workplaces (14 per cent) than unionised workplaces (9 per cent). By contrast, unionised workplaces were much more likely to experience voluntary redundancies (12 per cent) than were non-union workplaces (3 per cent) (Morehead et al 1997:419, and unpublished AWIRS data). A similar pattern can be seen in Britain (Sisson 1993:206). By August 2002 approximately 77 per cent of employees were non-union members (ABS Cat No 6310.0), suggesting that a large proportion of retrenched employees are likely to have been compulsorily retrenched.

\section{Prior job tenure}

A key factor in understanding the relationship between prior job tenure and labour market outcomes is age. (The term 'prior job' is used as short-hand in this text for 'job from which the employee was retrenched or made redundant'.) Older workers are more likely to have been in long duration jobs. In 2001, 71 per cent of retrenched workers aged 55-64 had prior job tenure of five years and over, as did 63 per cent of retrenched workers aged 45-54, compared to just 45 per cent of those aged 35-44 and 30 per cent of those aged 25-34. Retrenched employees with longer prior job tenure would be relatively disadvantaged as a consequence of their age, and because their skills and experience have been specific to a particular employer and they may not be readily transferable (Wooden, 1988:7). We turn, now, to various indicators of disadvantage amongst different groups of retrenched workers. 
Unemployed or not in the labour force

Table 3 shows the proportion of employees unemployed or not in the labour force amongst retrenched employees who were formerly in 'permanent' jobs, differentiated by tenure of prior job. The greatest disadvantage in 1997 was experienced by those with very short prior job tenure, and those with long prior tenure. While the situation improved for all groups between 1997 and 2001, the improvement was smallest for those with greater than 5 years job tenure (4 percentage points, compared to 9 percentage points for the 1 and under 5 years group, and 21 percentage points for the under 12 months group).

Table 3. Proportion unemployed or not in the labour force, July 1997, by duration of job from which retrenched or made redundant.

\begin{tabular}{|l|l|l|}
\hline & \multicolumn{2}{|l|}{$\begin{array}{l}\text { Proportion unemployed or not in the } \\
\text { labour force }\end{array}$} \\
\hline $\begin{array}{l}\text { Duration in Job from which } \\
\text { Retrenched or Made Redundant }\end{array}$ & $\begin{array}{l}\text { July 1997 } \\
\mathbf{( \% )}\end{array}$ & $\begin{array}{l}\text { July 2001 } \\
\mathbf{( \% )}\end{array}$ \\
\hline Under 12 months & 49.1 & 28.0 \\
\hline 1 and under 5 years & 34.3 & 24.9 \\
\hline 5 years and over & 39.4 & 35.2 \\
\hline Total & 40.4 & 30.2 \\
\hline
\end{tabular}

Source: ABS Cat No 6266.0, unpublished data.

Population: Persons aged 18 to 64 years who had been retrenched or made redundant from permanent jobs in the three years to 30 June 1997/2001 and were unemployed in July 1997/2001.

Changing from full-time to part-time status

There is evidence to suggest that 'retrenchment can be the catalyst to different, less secure forms of workforce attachment; that is, it can mark an individual's point of transition to "casualised" employment' (Webber and Webber 1999:110), which tends to be low skilled, involve little training, insecure and with few career prospects (Walley, Steinberg \& Waller 1999: 12). The literature also finds, 'almost universally', that re-employment, where it does occur, is frequently in less well paid jobs than those from which employees were retrenched (Wooden 1988:18). 
Another indicator of disadvantage amongst retrenched employees, then, is whether they have been able to resist reductions in their hours of work, from full-time to part-time. As shown in Table 4, retrenched employees with long prior job tenure are more likely than other retrenched employees to shift from full-time to part-time employment.

Table 4. Proportion of permanent employees who changed from full-time to part-time status, by duration in job from which retrenched or made redundant

\begin{tabular}{|l|l|l|}
\hline $\begin{array}{l}\text { Duration in Job from } \\
\text { which Retrenched or } \\
\text { Made Redundant }\end{array}$ & $\begin{array}{l}\text { Proportion of permanent employees who } \\
\text { changed from full-time to part-time status } \\
(\mathbf{\%})\end{array}$ \\
\hline & $\mathbf{1 9 9 7} \mathbf{2 0 0 1}$ \\
\hline under 12 months & 11.0 & 12.5 \\
\hline 1 and under 5 years & 13.5 & 12.0 \\
\hline 5 years \& over & 19.4 & 17.4 \\
\hline All & 14.9 & 14.3 \\
\hline
\end{tabular}

Source: ABS Cat No 6266.0, unpublished data.

Population: Persons aged 18 to 64 years who had been retrenched or made redundant in the three years to 30 June 1997/2001 and who were employed in July 1997/2001.

Is this switching from full-time to part-time status all voluntary? It seems unlikely. In the three years to February 2002, approximately 264,000 people or 4.2 per cent of all full-time employees switched to part-time jobs (ABS Cat No 6209.0). ${ }^{2}$ In the R\&R survey, some 56,400 people retrenched from full-time jobs ended up in part-time jobs over the three years to July 2001, equivalent to 11.6 per cent of retrenched full-time employees. This implies that approximately 3.5 per cent of non-retrenched full-time employees switched to part-time work over the threeyear period (and there is no reason to believe that all of the latter shifting is voluntary). ${ }^{3}$ That is,

\footnotetext{
${ }^{2}$ In the twelve months to February 2002, an estimated 94,800 full-timers converted to part-time jobs, as indicated above. In the twelve months to February 2000 the equivalent figure was 81,100. No estimate is available for February 2001 but a reasonable estimate would be the midpoint of these two figures, 88,000. These three figures sum to 263,900. The denominator is the number of people in full-time work in February 1999 in the Labour Mobility Survey, 6,329,600. See ABS, Labour Mobility, Cat No 6209.0.

3 The estimate is approximate as the two periods concerned have only an 81 per cent overlap, but this is not likely to have a major impact on the estimate. Calculated as $(263,900-56,400) /(6,329,600-484,200)$.
} 
retrenched employees were approximately 3.3 times as likely to switch from full-time to parttime work as other employees, suggesting a majority involuntary component to the shifting.

Of the 54,400 retrenched employees who switched from full-time to part-time jobs in the three years to 2001, most (69 per cent) switched from permanent full-time to casual part-time work. The ABS Forms of Employment Survey, undertaken four months later, found that amongst all part-time casual employees, 43 per cent wanted more hours (ABS Cat No 6359.0). Amongst male part-time casual employees, 53 per cent wanted more hours. The figure amongst retrenched employees now in casual part-time jobs was likely to be higher than this population average.

\section{Unemployment duration}

Table 5 shows unemployment duration of people who had been retrenched from a 'permanent' job in the previous three years and who were still unemployed. Some 51 per cent of retrenched employees with prior job tenure of five years or more had been unemployed for 26 weeks or more at the time of the ABS survey. Within this tenure group, disadvantage increased with tenure: amongst retrenched employees with prior job tenure of ten years or more, the figure was 59 per cent. 
Table 5. Unemployment duration, by previous job tenure.

\begin{tabular}{|c|c|c|c|}
\hline \multirow{2}{*}{$\begin{array}{l}\text { Duration of Current } \\
\text { Period } \\
\text { Unemployment }\end{array}$} & \multicolumn{3}{|c|}{$\begin{array}{c}\text { Duration in job from which retrenched or made } \\
\text { redundant }\end{array}$} \\
\hline & $\begin{array}{c}\text { in job for } \\
\text { under } 12 \\
\text { months (\%) }\end{array}$ & $\begin{array}{c}\text { in job for } 1 \\
\text { and under } 5 \\
\text { years (\%) }\end{array}$ & $\begin{array}{c}\text { in job for } 5 \\
\text { years and over } \\
(\%)\end{array}$ \\
\hline \multicolumn{4}{|l|}{1997} \\
\hline Under 8 weeks & 28.4 & 26.2 & 21.2 \\
\hline 8 and under 26 weeks & 24.0 & 32.8 & 27.3 \\
\hline 26 weeks and over & 47.8 & 41.0 & 50.8 \\
\hline All & 100.0 & 100.0 & 100.0 \\
\hline \multicolumn{4}{|l|}{2001} \\
\hline Under 8 weeks & 42.2 & 45.2 & 43.1 \\
\hline 8 and under 26 weeks & 39.8 & 28.2 & 31.0 \\
\hline 26 weeks and over & $18.1^{*}$ & 26.6 & 25.9 \\
\hline All & 100.0 & 100.0 & 100.0 \\
\hline
\end{tabular}

Note: $\quad$ Numbers in columns may not add to $100.0 \%$ due to rounding.

* Asterisked proportions based on estimates with a standard error of greater than 25 per cent.

Population: Persons aged 18 to 64 years who had been retrenched or made redundant from permanent jobs in the three years to 30 June 1997/2001 and were unemployed in July 1997/2001.

Source: ABS Cat No 6266.0, unpublished data.

Whereas in 1997 the proportion of retrenched people who suffered high duration unemployment was highest amongst those with prior job tenure of under 1 year and over 5 years, in 2001 the highest rates of high duration unemployment were experienced amongst those with prior job tenure of 1 to 5 years and over 5 years. On the surface this could appear to signify an improvement in the relative position of retrenched permanent employees with long prior job tenure in 2001, compared to 1997, to the point where they were in a similar position to retrenched employees with 1 to 5 years tenure. However, as discussed shortly, is almost certainly an 
illusion. In relation to indicators such as the proportion of retrenched employees who are unemployed or not in the labour force (Table 3) and switching from full-time to part-time employment (Table 4), the relative disadvantage faced by employees with long prior job tenure persisted. In addition, age, which continued to be strongly correlated to prior job duration, was still also correlated with the proportion of unemployed or not in the labour force (Table 2). Before seeking to understand this seeming paradox, we shall turn to evidence from another indicator of disadvantage, 'joblessness duration'.

\section{'Joblessness duration'}

While data on duration of current unemployment spells were collected by the ABS, directly analogous data for periods of being 'not in the labour force' were not collected. However, for all those people who are no longer currently employed (ie they are either unemployed or not in the labour force) we can calculate in grouped format the period of time since these retrenched employees lost their jobs (based on in what year the employees were retrenched). This is referred to here in shorthand as 'joblessness duration', though this is not quite accurate because it fails to take account of intervening periods of temporary employment that some employees may have experienced. Its usefulness is mainly in seeing whether similar relationships exist with tenure as are found in relation to unemployment duration - that is, it provides a reality check on the unemployment duration data.

Table 6 indicates that what we call 'joblessness duration', like unemployment duration, shows a marked bias towards retrenched employees from jobs with long prior tenure. That is, it confirms the disadvantage faced by employees retrenched from jobs with high prior tenure. Between 1997 and 2001 the incidence of high joblessness duration (ie of greater than 26 weeks) fell for all groups of permanent employees, but if anything the falls appeared to be weakest for those with prior job tenure of over 5 years (3.5 percentage points, compared to around 6 percentage points for the other two groups). 
Table 6. 'Joblessness' duration, by employment status and prior job tenure.

\begin{tabular}{|c|c|c|c|}
\hline \multirow{2}{*}{$\begin{array}{l}\text { Joblessness duration } \\
\text { (period of time since } \\
\text { retrenched) }\end{array}$} & \multicolumn{3}{|c|}{$\begin{array}{l}\text { Tenure in job from which retrenched or made } \\
\text { redundant }\end{array}$} \\
\hline & $\begin{array}{l}\text { in job for under } \\
12 \text { months (\%) }\end{array}$ & $\begin{array}{c}\text { in job for } 1 \text { and } \\
\text { under } 5 \text { years } \\
(\%)\end{array}$ & $\begin{array}{c}\text { in job for } 5 \\
\text { years and over } \\
(\%) \\
\end{array}$ \\
\hline \multicolumn{4}{|l|}{1997} \\
\hline \multicolumn{4}{|l|}{ Permanent employees } \\
\hline - $\quad$ under 26 weeks & 44.5 & 44.3 & 26.0 \\
\hline - 26 weeks and over & 55.5 & 55.7 & 74.0 \\
\hline - Total & 100.0 & 100.0 & 100.0 \\
\hline \multicolumn{4}{|l|}{ Casual employees } \\
\hline - under 26 weeks & 42.7 & 34.9 & $24.2^{*}$ \\
\hline - 26 weeks and over & 57.3 & 65.1 & $75.8^{*}$ \\
\hline - Total & 100.0 & 100.0 & 100.0 \\
\hline \multicolumn{4}{|l|}{2001} \\
\hline \multicolumn{4}{|l|}{ Permanent employees } \\
\hline - $\quad$ under 26 weeks & 50.2 & 50.5 & 29.5 \\
\hline - 26 weeks and over & 49.8 & 49.5 & 70.5 \\
\hline - Total & 100.0 & 100.0 & 100.0 \\
\hline \multicolumn{4}{|l|}{ Casual employees } \\
\hline - $\quad$ under 26 weeks & 48.3 & 46.7 & $25.0^{*}$ \\
\hline - 26 weeks and over & 51.7 & 53.3 & $75.0^{*}$ \\
\hline - Total & 100.0 & 100.0 & 100.0 \\
\hline
\end{tabular}

Note: Numbers in columns may not add to $100.0 \%$ due to rounding. 'Joblessness duration' as recorded here includes both: people who have been jobless for the entire period from when they were retrenched, up until the survey date; and people who have had jobs between being retrenched and the survey date but who were jobless at the time of the survey.

* Asterisked proportions based on estimates with a standard error of greater than 25 per cent.

Population: Persons aged 18 to 64 years who had been retrenched or made redundant in the three years to 30 June 1997/2001 and who were not employed in July 1997/2001.

Source: ABS Cat No 6266.0, unpublished data. 


\section{Unemployment duration revisited}

There appear to be three possible explanations for the pattern whereby declining estimated unemployment duration amongst employees with long prior job tenure seems to sit alongside the persistence of other indicators of disadvantage amongst this group. One might be that that there has been a significant increase in voluntary early retirement amongst older people, but we can quickly dismiss this explanation based on data presented above. Two other explanations are more plausible. One is that an increasing proportion of older retrenched people are leaving the labour market altogether, and this has disproportionately lowered average unemployment duration amongst those with long prior job tenure (the 'discouraged worker effect'). The other is that the apparent change reflects sampling variation between surveys (the 'sampling effect'). In fact, the 10.4 percentage point shift in relativities between the 1-5 year and 5+ years tenure groups was not statistically significant. Given this and the greater reliability of the LFS data as a whole, the sampling effect appears the more likely explanation.

\section{Casual/permanent employment status}

Do retrenched casual employees experience lesser labour market disadvantage than retrenched permanent employees of similar prior job duration? In these and other ABS data, casuals are employees without access to annual leave or sick leave. Accordingly, there can be 'casuals' who have worked in the same job for the same employer for several years. The term 'permanent' employees is used here simply as the opposite of 'casual', that is employees with holiday or sick leave.

We compare here the experience of retrenched casual employees with retrenched permanent employees who are entitled to severance benefits (those who have been with the employer for at least a year). Accordingly we focus on 'long term' casuals (those with 12 months or higher tenure). Persons aged 25 and over accounted for the vast majority - 82 per cent - of retrenched 'long term' casuals (ie those with 12 months or more service in their previous job). Indeed, 56 per cent were aged 35 or over. 'Long term' casuals accounted for one third of retrenched casual employees. 
Table 7 considers the differences between retrenched 'long term' casual employees and permanent employees with similar prior tenure, in terms of their chance of being unemployed or not in the labour force. The greater disadvantage experienced by retrenched long term casuals is apparent. Some 51 per cent of long term casuals who had been retrenched were still unemployed or out of the labour force in July 1997, compared to 37 per cent of permanent employees with similar job duration. In 2001, the gap was smaller but still to the disadvantage of long-term casuals. Retrenched casuals are disadvantaged relative to retrenched permanent employees in all age groups except the over 55 age group, in which the experiences of casuals and permanents are almost equally poor.

Table 7. Percentage unemployed or not in the labour force, by permanent or casual status of previous job, retrenched persons with prior job tenure of 12 months and over.

\begin{tabular}{|l|c|c|c|}
\hline Employment Status & $\begin{array}{c}\text { Proportion } \\
\text { unemployed }\end{array}$ & $\begin{array}{c}\text { Proportion } \\
\text { not in the } \\
\text { labour force }\end{array}$ & $\begin{array}{c}\text { Proportion } \\
\text { unemployed } \\
\text { or not in the } \\
\text { labour force } \\
\text { (\%) }\end{array}$ \\
\hline $\mathbf{1 9 9 7}$ & 18.6 & 18.6 & $\mathbf{3 7 . 2}$ \\
\hline $\begin{array}{l}\text { Permanent employees with 12 } \\
\text { months or more prior job tenure }\end{array}$ & 27.7 & 23.5 & $\mathbf{5 1 . 1}$ \\
\hline $\begin{array}{l}\text { Casual employees with 12 } \\
\text { months or more prior job tenure }\end{array}$ & 20.0 & 19.4 & 39.4 \\
\hline $\begin{array}{l}\text { All employees } \\
\text { 2001 }\end{array}$ & 13.7 & 16.9 & $\mathbf{3 0 . 7}$ \\
\hline $\begin{array}{l}\text { Permanent employees with 12 } \\
\text { months or more prior job tenure }\end{array}$ & 16.5 & 21.2 & $\mathbf{3 7 . 7}$ \\
\hline $\begin{array}{l}\text { Casual employees with 12 } \\
\text { months or more prior job tenure }\end{array}$ & 14.2 & 17.6 & 31.8 \\
\hline \\
All employees
\end{tabular}


Source: ABS Cat No 6266.0, unpublished data.

Population: Persons aged 18 to 64 years who had been retrenched or made redundant in the three years to 30 June 1997/2001 from jobs with tenure of 12 months or more.

When measured by unemployment duration, retrenched long term casuals are more disadvantaged than are equivalent retrenched 'permanent' employees (table 8). In 2001, while 26 per cent of unemployed persons in the latter group had unemployment duration of at least 26 weeks, the same was the case for about 41 per cent of the former group. Table 6, shown earlier, also confirms that in terms of 'joblessness duration' the position of retrenched long term casuals is at least as bad, and probably worse, than that of retrenched permanent employees with similar prior job duration.

Table 8. Unemployment duration, by permanent or casual status, retrenched persons employed for 12 months and over job duration.

\begin{tabular}{|l|c|c|}
\hline $\begin{array}{l}\text { Duration of Current } \\
\text { Period } \\
\text { Unemployment }\end{array}$ & \multicolumn{2}{|c|}{ Distribution of unemployment duration } \\
\hline & $\begin{array}{r}\text { Permanent employees } \\
\text { with 12 months or } \\
\text { more prior job tenure } \\
\text { of } \\
\text { months or more prior } \\
\text { job tenure }\end{array}$ \\
\hline 1997 & $\begin{array}{c}\text { Casual } \\
\text { mith 12 }\end{array}$ \\
\hline Under 8 weeks & 24.2 & $25.0^{*}$ \\
\hline 8 and under 26 weeks & 30.7 & $18.5^{*}$ \\
\hline 26 weeks and over & 44.8 & 56.5 \\
\hline Total & 100.0 & 100.0 \\
\hline 2001 & 44.2 & $41.3^{*}$ \\
\hline Under 8 weeks & 29.5 & $16.3^{*}$ \\
\hline 8 and under 26 weeks & & \\
\hline
\end{tabular}




\begin{tabular}{|l|c|c|}
\hline 26 weeks and over & 26.3 & $41.3^{*}$ \\
\hline Total & 100.0 & 100.0 \\
\hline
\end{tabular}

Note: Numbers in columns may not add to $100.0 \%$ due to rounding.

* Asterisked proportions based on estimates with a standard error of greater than 25 per cent.

Population: Persons aged 18 to 64 years who had been retrenched or made redundant in the three years to 30 June 1997/2001 from jobs with tenure of 12 months or more.

Source: ABS Cat No 6266.0, unpublished data.

With casual employment possibly becoming 'more secure in terms of regularity of earnings and predictable working patterns, along with high expectations of continued employment for casual employees with their current employer' (Australia 2003:174), it seems that the larger difference between long-term casuals and permanents is not in their expectations of continuing employment but in the degree of disadvantage they face when retrenched - and, given the low costs of doing so, the incentive on employers to retrench them.

\section{Concluding comments}

Older retrenched persons and those with long prior job tenure face higher labour market disadvantage than younger ones and those with shorter tenure. Those with long prior job tenure face a lower probability of finding future employment than other retrenched employees, though those with very short tenure face different difficulties in the labour market. Those with long tenure also face a higher probability of being forced to shift from full-time to part-time employment if they do manage to find future employment. The most important reason for this is age. Older retrenched workers are clearly disadvantaged in the labour market.

In 2003 Queensland Industrial Relations Commission (QIRC) handed down its decision on severance benefits and in 2004 the Australian Industrial Relations Commission (AIRC) did so. Though the decisions differed in detail, both tribunals decided to maintain severance benefits for workers with tenure of up to four years, but raised those for workers with longer prior job tenure, doubling them for workers with nine (AIRC) or twelve (QIRC) years service. Queensland's rationale for increasing payments focused principally on the need for social justice for longtenured retrenched workers who lost valuable credits such as sick leave and long service leave, 
faced the prospect of never finding 'similar work or work that provides them with the level of remuneration received in the position from which they were retrenched', and the costs they face due to the need for extensive retraining or study into new areas (QIRC 2003:10). The AIRC focused on maintaining the rationale for the 1984 TCR decision and redressing the anomaly whereby it was recognised that hardship increased with tenure but the scale of benefits did not increase after four years service (AIRC 2004:44).

Both declined to apply any loading for older workers. For Queensland this was principally because of fear this would exacerbate discrimination against older workers, but it recognised that long-tenured workers also happened to be older workers. The AIRC also considered that tenurebased scales took age indirectly into account, but added that the extra difficulty experienced by older retrenched workers in finding employment was not relevant as it was 'not appropriate to take income maintenance considerations into account' (AIRC 2004:46). This was the role of the social security system, notwithstanding the fact that many retrenched workers are ineligible for social security payments because they have an employed spouse (AIRC 2004:39-40). Still, while allocating compensation based on tenure rather than age is imperfectly targeted at employees most disadvantaged in retrenchment situations, it at least goes some way to achieving this in a way least likely to cause offence to employers.

As for casual employees, the data demonstrate that the position of retrenched long term casuals is at least as difficult as that facing retrenched permanent employees with similar job tenure and in most respects is more difficult. They face longer periods of unemployment than equivalent permanent employees, and lower probabilities of finding work. Yet they receive no severance benefits except when union pressure is successfully applied. The QIRC declined to grant casuals a severance entitlement, but also kept open the door for reopening the application pending the upcoming AIRC decision. On the one hand it considered that a severance benefit was incorporated into the casual loading, on the other that the 'the term "casual" now encompasses a wide variety of types of employment. The "traditional" casual is but one of those types' and the Commission had 'some sympathy for those non-traditional long term casuals who are displaced as a result of retrenchment' (QIRC 2003:16). The AIRC was more decisive, rejecting any compensation for casuals on the grounds that this would be 'double dipping', as one factor taken 
into account in an increase in the casual loading in the Metals Award in 2000 was the lack of redundancy benefits for casuals (AIRC 2004:83).

While the decision may be reasoned, the outcome is clearly inequitable for casual employees. Implicitly, policy makers expect long term casual employees to put money aside each week to cover the potential hardship associated with redundancy, just as they are expected to do the same in relation to annual leave and sick leave. Whatever the merits of requiring them to save up for their relatively predictable annual leave each year, it is quite unrealistic to imagine this happens for the unpredictable contingency of redundancy. Even if the casual loading encompasses compensation for lack of access to redundancy pay - and outside of the Metals case it is highly debatable as to whether this is the case - it represents an inefficient distribution of compensation and is of little practical benefit to casuals when they are retrenched. Whatever the significance of the casual loading, it is difficult to see how older workers with ten or more years service to an employer, retrenched into difficult labour market circumstances, facing even greater difficulties than permanent employees with similar age and tenure, should be denied severance benefits merely because they are classified as a casual employee - that is, not given annual and sick leave - by their employing organisation. The data presented here, and the treatment of casuals in the decision, call into serious question the nature of the regulation of casual employment. With many casual employees not being 'genuinely' casual, the proliferation of long term casual employment has become a mechanism by which over a quarter of the workforce are defined outside of the safety net that ostensibly provides rights of access to recreation leave, sick leave and redundancy benefits to Australian employees. It would seem an appropriate time for policy makers, including those in unions, to rethink the role of 'casual' employment in modern society, as the relationship between casual employment and redundancy pay shines light through one of the more significant holes in the safety net.

\section{Acknowledgements}

My thanks go to Robin Price and Chris Houghton for research assistance with aspects of this paper. 


\section{References}

Australia (2003) Commonwealth Government Submission to Australian Industrial Relations Commission Redundancy and Termination of Employment Case, Department of Employment and Workplace Relations, Canberra.

Australian Bureau of Statistics [ABS] Cat No 6310.0 - Employee Earnings, Benefits and Trade Union Membership, Australia

----- Cat No 6359.0 - Forms of Employment, Australia

Campbell, I (1996) 'Casual Employment, Labour Market Deregulation and Australian Trade Unions', in G Griffin (ed) Contemporary Research on Unions: Theory, Membership, Organisation and Non-standard Employment, Volume 1, Monograph No 7, National Key Centre in Industrial Relations, Monash University, 173-206.

McNabb, R \& Ryan, P (1990) 'Segmented labour markets', in Z Tzannatos and D Sapsford (eds), Current issues in labour economics, MacMillan, Melbourne: 151-176.

Morehead, A, Steele, M, Alexander, M, Stephen, K \& Duffin, L (1997) Changes at Work: The 1995 Australian Workplace Industrial Relations Survey, Longman.

Murtough, G \& Waite, M (2000) 'The growth of non-traditional employment: Are jobs becoming more precarious?', Staff Research Paper, Productivity Commission, July.

Pocock, B (1998) 'All Change, Still Gendered: The Australian Labour Market in the 1990s', Journal of Industrial Relations, 40(4), 580-604.

Queensland Industrial Relations Commission (QIRC), Decision, No B209 of 2002 and No B308 of 2002, 18 August, in QGIG 171(18), 1417-1429.

Riach, P A \& Rich, J (1991) 'Testing for racial discrimination in the labour market', Cambridge Journal of Economics, 15(3): 239-256.

VanderHeuvel, A. (1999) "Mature age workers: are they a disadvantaged group in the labour market?” Australian Bulletin of Labour. 25 (1): 11-22.

Walley, L, Steinberg, M \& Warner, D (1999) The Mature Age Labour Force, Workforce Strategy Unit, Employment Taskforce, Monograph series No.2, Department of Employment, Training and Industrial Relations, Brisbane, May.

Webber, M. \& Campbell, I. (1997) "Labour market outcomes among retrenched workers in Australia: a review” Australian and New Zealand Journal of Sociology. 33 (2): 187-204. 
Wooden, M. (1988) “The impact of redundancy on subsequent labour market experience” Journal of Industrial Relations. 30 (1): 3-31.

Workers Online (2002), 'Cyber Action Behind Hilton Win', Workers Online [WWW] Labor Council of NSW, Sydney, 1 November, http://workers.labor.net.au/159/news5_hilton.html. 